\title{
Natural history of the critically endangered salamander Ambystoma leorae (Caudata: Ambystomatidae) from the Río Tonatzin, Mexico
}

\author{
Julio A. Lemos-Espinal, ${ }^{1}$ Geoffrey R. Smith, ${ }^{2}$ Aline B. Estrella Zamora, ${ }^{1}$ Guillermo Woolrich- \\ Piña, ${ }^{3}$ and Raymundo Montoya Ayala ${ }^{4}$ \\ ${ }^{1}$ Laboratorio de Ecología-UBIPRO, Facultad de Estudios Superiores Iztacala, Av. Los Barrios 1, Los Reyes Iztacala, \\ Tlalnepantla, Estado de México, 54090, Mexico. E-mail: lemosj44@yahoo.com.mx. \\ ${ }^{2}$ Department of Biology, Denison University, Granville, OH 43023, USA. \\ ${ }^{3}$ Laboratorio de Zoología, División de Biología, Subdirección de Investigación y Posgrado, Instituto Tecnológico Superior de \\ Zacapoaxtla, Carretera Acuaco Zacapoaxtla km 8, Col. Totoltepec, Zacapoaxtla, Puebla, Mexico. \\ ${ }^{4}$ Laboratorio de Cómputo-UBIPRO, Facultad de Estudios Superiores Iztacala, Av. Los Barrios 1, Los Reyes Iztacala, \\ Tlalnepantla, Estado de México, 54090, Mexico.
}

\begin{abstract}
Natural history of the critically endangered salamander Ambystoma leorae (Caudata: Ambystomatidae) from the Río Tonatzin, Mexico. In Mexico, many species of Ambystoma are endangered, but unfortunately little is known about their natural history and ecology. We report on aspects of the natural history of A. leorae, a critically endangered endemic salamander, from the Río Tonatzin, State of México, Mexico. We observed egg masses, which were attached to vegetation, from April to June, with a mean of 7.28 eggs per egg mass. Larval A. leorae were found in sections of the Río Tonatzin with muddy bottoms and submerged aquatic vegetation. We observed adult and juvenile salamanders throughout the year except September, but with a peak from May to July. The use of sites along the Río Tonatzin by adult and juvenile A. leorae was driven primarily by vegetation type and substrate type of the site, with mud or sand substrate with grass roots and submerged aquatic vegetation being the most used site types. We found no evidence of sexual dimorphism in A. leorae. Our results suggest that adult and juvenile A. leorae use a variety of stream sites, although larvae appear to be more limited in their use of stream sites. These observations indicate that to maintain this population of A. leorae, the general conditions existing in the Río Tonatzin should be protected, especially the sections with muddy bottoms and aquatic vegetation where larvae, juveniles, and adults are found.
\end{abstract}

Keywords: adults, aquatic vegetation, eggs, juveniles, sexual dimorphism, substrate, water speed.

Received 14 December 2016

Accepted 17 May 2017

Distributed June 2017 


\begin{abstract}
Resumen
Historia natural de la salamandra críticamente en peligro de extinción Ambystoma leorae (Caudata: Ambystomatidae) del Río Tonatzin, México. En México, muchas especies de Ambystoma están en peligro de extinción, desafortunadamente poco se conoce de sus historias naturales y ecología. En este estudio, reportamos aspectos de la historia natural de A. leorae, una salamandra endémica críticamente en peligro de extinción, para la población del Río Tonatzín, estado de México, México. Observamos masas de huevos pegadas a la vegetación, desde abril hasta junio, con un promedio de 7,28 huevos por masa de huevos. Larvas de A. leorae fueron encontradas en secciones del Río Tonatzín con fondos lodosos y vegetación acuática sumergida. Observamos salamandras adultas y juveniles a través de todo el año, excepto en septiembre, con un pico desde mayo hasta julio. El uso de sitios a lo largo del Río Tonatzin por adultos y juveniles de A. leorae fue motivado principalmente por el tipo de vegetación y el tipo de sustrato del sitio, con lodo o sustrato de arena, con raices de zacate amacollado y vegetación acuática sumergida que son los tipos de sitios más utilizados. No encontramos evidencia de dimorfismo sexual en A. leorae. Nuestros resultados sugieren que adultos y juveniles de A. leorae utilizan una variedad de sitios de arroyo, aunque las larvas parecen estar más limitadas en la utilización de estos sitios. Estas observaciones indican que para mantener esta población de A. leorae, las condiciones generales existentes en el Río Tonatzín deben ser protegidas, especialmente las secciones con fondos lodosos y vegetación acuática donde se encuentran las larvas, juveniles y adultos.
\end{abstract}

Palabras clave: adultos, dimorfismo sexual, huevos, juveniles, sustrato, vegetación acuática, velocidad del agua.

Resumo

História natural da salamandra criticamente ameaçada Ambystoma leorae (Caudata: Ambystomatidae) do Rio Tonatzin, México. Muitas espécies de Ambystoma do México acham-se ameaçadas de extinção, e infelizmente pouco se sabe de sua história natural e ecologia. Neste estudo, fornecemos dados sobre a história natural de A. leorae, uma salamandra endêmica e criticamente ameaçada, para a população do Rio Tonatzín, estado do México, México. Observamos massas de ovos aderidas à vegetação de abril a junho, com uma média de 7,28 ovos por desova. Larvas de A. leorae foram encontradas em trechos do Rio Tonatzín com fundo lodoso e vegetação aquática submersa. Observamos salamandras adultas e juvenis ao longo de todo o ano, exceto em setembro, com pico de maio a julho. O uso de locais ao largo do Rio Tonatzin por adultos e juvenis de A. leorae dependeu primariamente do tipo de vegetação e do tipo de substrato, sendo lodo ou substrato de areia com raízes de gramíneas e vegetação aquática submersa os tipos de locais mais utilizados. Não encontramos evidência de dimorfismo sexual em A. leorae. Nossos resultados sugerem que adultos e juvenis de $A$. leorae utilizam uma grande variedade de locais de riachos, ainda que as larvas pareçam estar mais limitadas na utilização desses locais. Essas observações indicam que, para que essa população de A. leorae seja preservada, as condições gerais existentes no Rio Tonatzín devem ser protegidas, especialmente os trechos com fundo lodoso e vegetação aquática onde são encontradas larvas, juvenis e adultos.

Palavras-chave: adultos, dimorfismo sexual, juvenis, ovos, substrato, vegetação aquática, velocidade da água. 


\section{Introduction}

In Mexico, eight of the 18 (44\%) species of salamanders in the genus Ambystoma are critically endangered, and another three species are considered endangered by the IUCN (The IUCN Red List of Threatened Species, Version 2014.2; www.iucnredlist.org). One of the critically endangered species is A. leorae (Taylor, 1943). Ambystoma leorae has an Environmental Vulnerability Score of 15 , which is within the high vulnerability range (Wilson et al. 2013), and is considered Threatened by the Mexican government (SEMARNAT 2010). Many populations of Mexican Ambystoma are subject to several anthropogenic threats, including urbanization and suburbanization, pollution, conversion to agriculture, and the introduction of fish (e.g., Lemos-Espinal et al. 1999, Griffiths et al. 2004, Contreras et al. 2009, Frías-Alvarez et al. 2010), as well as the possible threat of Batrachochytrium dendrobatidis Longcore, Pessier, and Nichols (Frías-Alvarez et al. 2008; see also Mendoza-Almeralla et al. 2015). Several Mexican Ambystoma have small, isolated populations that are prone to extinction (see Parra-Olea et al. 2012), including A. leorae (Sunny et al. 2014a,b). The expansion of Mexico City is of particular concern and likely affects the populations of Ambystoma in the natural areas surrounding it, including A. leorae (MonroyVilchis et al. 2015), especially given recent degradation of the forest in the vicinity (GarcíaRomero 2002; see also Merlín-Uribe et al. 2013).

As with many other species of Ambystoma in Mexico, little is known about the natural history of A. leorae. Ambystoma leorae was originally described from near Río Frío, Mexico by Taylor (1943). Ambystoma leorae have been found in pools along streams with slow moving water, sand or rock substrates, cool water, and high dissolved oxygen levels (Vega-López and Alvarez-S. 1992, Sunny et al. 2014a, MonroyVilchis et al. 2015). The diet of A. leorae primarily consists of aquatic insects (VegaLópez and Alvarez-S. 1992). Dyer and Brandon
(1973) reported some new host records of parasitic nematodes in A. leorae. Ambystoma leorae lay a mean clutch size of 4.4 eggs (range 1-10) with eggs attached to vegetation (Sunny et al. 2014a). The maximum body size of A. leorae to date is $103 \mathrm{~mm} \mathrm{SVL}$ (Lemos-Espinal and Ballinger, 1994). This species of salamander shows relatively high levels of genetic diversity (Sunny et al. 2014b). Additional information on A. leorae is needed to better understand its conservation and management. Here we report on the distribution of eggs, larvae, juveniles, and adults in the stream and body size and sexual dimorphism of A. leorae from the Río Tonatzin, State of México, Mexico.

\section{Materials and Methods}

\section{Study Site}

We recorded individuals of $A$. leorae in Río Tonatzin, a permanent stream located 7.5-8.8 km northeast of the town of Río Frío, municipality of Ixtapaluca, state of México, Mexico $\left(19^{\circ} 22^{\prime} 2.9^{\prime \prime} \mathrm{N}, 98^{\circ} 39^{\prime} 28.8^{\prime \prime} \mathrm{W}\right.$ to $19^{\circ} 22^{\prime} 18.7^{\prime \prime} \mathrm{N}$, 98³9'30.2" W; 3012 m a.s.l.). The Río Tonatzin is a small stream surrounded by a mixed forest consisting primarily of Pine (Pinus montezumae Lamb. and $P$. hartwegii Lindl.), Religious Fir [Abies religiosa (Kunth) Schltdl. \& Cham.], a variety of Oak trees (mainly Quercus rugosa Née and Q. laurina Bonpl.), and Mexican Alder (Alnus jorullensis Kunth). The understory includes Mexican Strawberry Tree (Arbutus glandulosa M Martens \& Gal.), Manzanita (Arctostaphylos arguta Zucc.), Mexican Lupine (Lupinus elegans Kunth), Pineapple Sage (Salvia elegans Vahl), Old-man Bush (Senecio angulifolius DC.), Toluca Bentgrass (Agrostis tolucensis Kunth), Fescue Grass (Festuca sp.), and Mühlenberg Grass (Mühlenbergia sp.). This portion of the stream, $2 \mathrm{~km}$ in length, has a gentle slope that results in a constant flow of water. Most of the stream is sinuous with a number of curves where water has eroded the stream banks producing small caves or crevices 
in them. The bottom of the stream consists of mud, sand, gravel, or bed rock. The width of the stream varies from 44 to $378 \mathrm{~cm}$, and the depth from 14 to $134 \mathrm{~cm}$. Through the year dissolved oxygen levels range from 3.01 to $6.89 \mathrm{ppm}$, and the temperature from 6.1 to $18.8^{\circ} \mathrm{C}$.

\section{Methods}

We visited the Río Tonatzin monthly from October 2015 through September 2016. For safety and logistic reasons, sampling took place during the day. On each visit, we walked $2 \mathrm{~km}$ along the stream with the starting point for each visit shifted so that sites were not visited more than once during the study. Along this $2 \mathrm{~km}$ section of the stream, we surveyed 25 arbitrarily selected sites along the stream (so 25 sites per month). Each site was, on average, $75 \mathrm{~m}$ from the neighboring sites (generally 50 to $100 \mathrm{~m}$ ). In an effort to sample a greater proportion of the stream across the study period, site selection for one visit was independent of site selection for other visits. Thus, some sites may have been sampled more than once across the entire study period, but specific sites were not repeatedly sampled over the course of the study, and it is unlikely specific sites were sampled more than once during the course of this study. Each site consisted of a $3 \mathrm{~m}$ linear section of the stream. Within each site, we carefully searched the stream section visually and by using a snake hook along the bottom of the stream and in depressions in the side of the stream to induce movement by any salamanders, thus making them obvious. We also looked under all rocks or other objects in the stream section. Using these methods to thoroughly search every site and given the small area searched at each site $(<5$ $\mathrm{m}^{2}$ ), we are confident that we detected most salamanders (adults, larvae, and eggs) within each site. However, since we only visited each specific site once during the course of the study we could not estimate detection probabilities (Mazerolle et al. 2007). Other studies have estimated detection probabilities for Ambystoma from 0.459 to 0.89
(Corn et al. 2005, Hossack and Corn 2007, Gorman et al. 2009, Peterman et al. 2013); however, all of these refer to larger pond or wetland habitats and not to streams or sites as small as our sites. Detection probabilities of nonambystomatid salamanders in streams range from 0.39-0.96 (Jung et al. 2005, Kroll et al. 2010).

We captured salamanders with a net and measured snout-vent length (SVL; tip of snout to anterior margin of vent) and body mass of each captured individual. We determined the sex of each salamander based on the presence of swelling of the cloacal region on both sides of the tail in males and a lack of swelling in females (Brandon and Altig 1973). We released salamanders at the point of capture once measurements were completed.

We measured the width and depth of the stream of each site to the nearest $\mathrm{cm}$. We measured dissolved oxygen and water temperature using a YSI model 85 meter (YSI Incorporated, Yellow Springs, Ohio). We measured water speed at the surface and in the middle of the water column using a Global Water Flow Probe Hand-held Flowmeter (Xylem Inc., White Plains, New York). We also characterized the vegetation at each site as grass roots (in crevices in the stream bank), submerged aquatic plants and algae, or no vegetation. We categorized substrate type as mud, mud with gravel, gravel, bedrock, or sand. We also recorded the microhabitat [near water surface (i.e., within $15 \mathrm{~cm}$ of surface), in algae, in crevice in stream bank, or on the stream bottom] of each individual salamander.

We used a generalized linear model (with binomial distribution) with presence or absence of adult juvenile A. leorae as the dependent variable and the abiotic stream characteristics as the independent variables. Because of the small number of sites in which we observed larvae and eggs, we did not conduct an analysis and report only statistics for the occupied sites. We compared SVL between the sexes using an ANOVA. We compared body mass between the sexes using an ANCOVA with SVL as covariate. 
Statistical analyses were performed using JMP Pro 10.0.0 (SAS Institute, Cary, North Carolina). Means are given $\pm 1 \mathrm{SE}$.

\section{Results}

\section{Observations of Eggs and Larvae}

We observed a total of seven egg masses from April to June 2016. Two egg masses were seen in April, two in May, and three in June. Mean number of eggs per mass was $7.28 \pm 0.47$ (range 6-9). All egg masses were attached to vegetation. Egg masses were all found at sites with mud bottoms $(N=7)$, and in sites with submerged aquatic plants and algae $(N=6)$ or no vegetation $(N=1)$. Stream sites with egg masses were $69 \pm 4.8 \mathrm{~cm}$ wide $(N=7)$ and $57 \pm 7.4 \mathrm{~cm}$ deep $(N=7)$. Mean dissolved oxygen of sites with egg masses was $6.1 \pm 0.3 \mathrm{mg} / \mathrm{L}(N=7)$. Water temperature averaged $15.3 \pm 0.8^{\circ} \mathrm{C}(N=7)$. Surface water speed averaged $0.134 \pm 0.027 \mathrm{~m} / \mathrm{s}$ $(N=7)$ and water speed in the middle of the water column averaged $0.030 \pm 0.006 \mathrm{~m} / \mathrm{s}(N=7)$.

Larval A. leorae were observed from May to August at three sites in May, two sites in June, and one site each in July and August. Larval A. leorae were only found in sites with mud bottoms $(N=7)$ and submerged aquatic vegetation and algae $(N=7)$. Individual larval $A$. leorae were found near the water surface $(N=25)$ or hidden in algae $(N=8)$. The mean stream width of sites where larval A. leorae were found was $121.3 \pm$ $21.2 \mathrm{~cm}(N=7)$. Mean depth of sites with $A$. leorae larvae was $72.6 \pm 11.9 \mathrm{~cm}(N=7)$. Dissolved oxygen levels of sites with A. leorae larvae was $6.49 \pm 0.10 \mathrm{mg} / \mathrm{L}(N=7)$. Mean temperature was $13.9 \pm 1.1^{\circ} \mathrm{C}(N=7)$. The water speed at the surface averaged $0.24 \pm 0.10 \mathrm{~m} / \mathrm{s}(N$ $=7$ ) and at the middle of the water column averaged $0.028 \pm 0.028 \mathrm{~m} / \mathrm{s}(N=7)$.

\section{Observations of Adults and Juveniles}

We made a total of 157 observations of individual adult and juvenile salamanders. We observed salamanders in all months of the study except September 2016 (Table 1). The number of salamanders observed was highest in MayJuly (Table 1).

Stream use.-The generalized linear model of the stream characteristics was significant (whole model test: $\chi^{2}=155.84, p<0.0001$ ). We present the results of this analysis in Table 2. Vegetation type and bottom type were the most significant terms in the model with vegetation type being the most important variable by far (i.e., greatest $\log$ worth). Dissolved oxygen, month, and substrate color were also significant. All other variables were not significant.

Below and in Table 3 we provide summaries or summary statistics for the stream characteristics we examined in the generalized linear model. We found $A$. leorae adults and juveniles on mud $(N=14)$, sand $(N=9)$, and mud and gravel $(N=$ 3 ) substrates. We did not observe A. leorae on gravel or bedrock. Adult and juvenile A. leorae primarily used crevices in the stream bank $(N=$ $10)$ or were near the water's surface $(N=12)$, with the stream bottom $(N=1)$ and algae $(N=4)$ used less often. If we examine the stream use of individual $A$. leorae adults and juveniles as opposed to sites, we found $40.5 \%(N=47)$ of individuals on mud substrates, $30 \%(N=35)$ on mud and gravel substrate, and $29.3 \%(N=34)$ on sand. We observed $44.0 \%(N=51)$ of individuals in grass roots, $35.3 \%(N=41)$ in submerged aquatic vegetation and algae, and $20.7 \%(N=$ $24)$ in no vegetation. Most individuals were found either in crevices in the stream wall $(44.8 \% ; N=52)$ or near the water surface (50.9\%; $N=59$ ), and only rarely did we find individuals on the stream bottom $(1.7 \% ; N=2)$ or hidden in algae $(2.6 \% ; N=3)$.

Body size and sexual dimorphism.-Male and female A. leorae did not differ in SVL [Males: $76.7 \pm 1.6 \mathrm{~m}(N=41)$; Females: $76.4 \pm$ $1.4 \mathrm{~mm}(N=57)$; ANOVA: $\mathrm{F}_{1,96}=0.028, p=$ 0.87]. Body mass of male and female A. leorae did not differ either [Males: $19.5 \pm 0.98 \mathrm{~g}(N=$ 41); Females: $19.2 \pm 0.86 \mathrm{~g}(N=57)$; 
Table 1. Number of adult and juvenile Ambystoma leorae observed along the Río Tonatzin, State of México, Mexico, in each month of the study. Number of sites is 25 for all months.

\begin{tabular}{cccccccccccccc}
\hline Year & \multicolumn{10}{c}{$\mathbf{2 0 1 5}$} & \multicolumn{10}{c}{$\mathbf{2 0 1 6}$} \\
\hline & Oct & Nov & Dec & Jan & Feb & Mar & Apr & May & Jun & Jul & Aug & Sep \\
\hline$N$ & 6 & 4 & 3 & 6 & 6 & 10 & 15 & 35 & 30 & 28 & 14 & 0 \\
\hline
\end{tabular}

Table 2. Results of a generalized linear model of the presence and absence of Ambystoma leorae using stream characteristics.

\begin{tabular}{lccc}
\hline Variable & Log Worth & $\boldsymbol{p}$ & Parameter Estimate \\
\hline Vegetation type & 26.44 & $<0.0001$ & 2.52 \\
Bottom type & 5.79 & $<0.0001$ & -0.97 \\
Month & 2.55 & 0.0028 & 0.153 \\
Dissolved oxygen $(\mathrm{mg} / \mathrm{L})$ & 1.88 & 0.0132 & -0.335 \\
Substrate color & 1.66 & 0.0219 & 0.73 \\
Stream depth $(\mathrm{cm})$ & 0.65 & 0.22 & -0.0091 \\
Water speed middle of water column $(\mathrm{m} / \mathrm{s})$ & 0.34 & 0.46 & 3.00 \\
Water temperature $\left({ }^{\circ} \mathrm{C}\right)$ & 0.14 & 0.72 & -0.019 \\
Surface water speed $(\mathrm{m} / \mathrm{s})$ & 0.10 & 0.80 & -0.26 \\
Stream width $(\mathrm{cm})$ & 0.04 & 0.90 & -0.0004 \\
\hline
\end{tabular}

ANCOVA: $\left.\mathrm{F}_{1,95}=0.026, p=0.87\right]$. Body mass increased with SVL (ANCOVA: $\mathrm{F}_{1.95}=1119.3$, $p<0.0001$; Body mass $=-26.4+0.60 \mathrm{SVL})$.

\section{Discussion}

Our observations suggest that egg laying by A. leorae takes place from April to June. This is similar to the timing of egg laying in other Mexican Ambystoma, including a previous report for A leorae. Sunny et al. (2014a) reported finding eggs of A. leorae from February to June. Ambystoma altamirani Dugès, 1895 lay eggs in June (Lemos-Espinal et al. 2016), and A. rosaceum Taylor, 1941 have been recorded as laying eggs in April (Anderson 1961, Anderson and Webb 1978, Tanner 1989). These observations coincide with the wet or rainy season in central Mexico.
We observed egg masses of A. leorae attached to aquatic vegetation. Sunny et al. (2014a) also found A. leorae eggs attached to vegetation, as well as in "caves". Ambystoma altamirani and A. ordinarium Taylor, 1940 also attach their eggs to vegetation (Anderson and Worthington 1971, Brandon and Altig 1973, Lemos-Espinal et al. 2016). Ambystoma rivulare (Taylor, 1940) attach their eggs to twigs and pine needles (Bille 2009), but also place their eggs under logs or rocks (Brandon and Altig 1973, Anderson and Webb 1978). However, A. rosaceum place their eggs exclusively under rocks or logs (Brandon and Altig 1973, Anderson and Webb 1978). Why some species of Mexican Ambystoma place their eggs under cover objects whereas others attach them to other structures in the water column is not clear, and represents a question that might be pursued in future research. 
Table 3. Mean ( \pm 1SE) of characteristics of stream locations along the Río Tonatzin, State of México, Mexico with and without Ambystoma leorae pooled across all months and years (October 2015 through September 2016).

\begin{tabular}{lcc}
\hline Characteristic & With $\boldsymbol{A}$. leorae $(\mathbf{N}=\mathbf{2 6})$ & Without $\boldsymbol{A}$. leorae $(\mathbf{N}=\mathbf{2 7 4})$ \\
\hline Stream width $(\mathrm{cm})$ & $128.8 \pm 10.0$ & $145.0 \pm 3.2$ \\
Stream depth $(\mathrm{cm})$ & $69.1 \pm 4.9$ & $70.0 \pm 1.3$ \\
Dissolved oxygen $(\mathrm{mg} / \mathrm{L})$ & $5.50 \pm 0.24$ & $5.37 \pm 0.08$ \\
Water temperature $\left({ }^{\circ} \mathrm{C}\right)$ & $14.0 \pm 0.5$ & $14.4 \pm 0.2$ \\
Surface water speed $(\mathrm{m} / \mathrm{s})$ & $0.036 \pm 0.009$ & $0.034 \pm 0.003$ \\
Middle water speed $(\mathrm{m} / \mathrm{s})$ & $0.003 \pm 0.002$ & $0.003 \pm 0.001$ \\
\hline
\end{tabular}

We found a mean egg mass size of 7.28 eggs for A. leorae (range $=6-9$ ). This is slightly higher than the mean of 4 for A. leorae (range = 1-10) reported by Sunny et al. (2014a), but these observations both suggest a relatively small egg mass for this species.

Our results suggest that the use of sites along the Río Tonatzin by A. leorae adults and juveniles is driven primarily by vegetation type (sites with submerged aquatic vegetation), as well as bottom type, dissolved oxygen, month, and substrate color (see Table 2). Our observations on the importance of vegetation type and substrate type for the use of sites by A. leorae along the Río Tonatzin is consistent with results of a study of another Mexican Ambystoma that compared sites with and without salamanders. Ambystoma altamirani used stream sites that held a greater volume of water, with higher dissolved oxygen levels, faster moving water, black substrates, and emergent vegetation than expected; and avoided sites with no vegetation and gravel and bedrock substrates (LemosEspinal et al. 2016; see also Taylor and Smith 1945, Maldonado-Koerdell 1947, Brandon and Altig 1973, Lemos-Espinal et al. 1999). On a broader level our results are consistent with observations of A. leorae and other Mexican Ambystoma in that they occupy narrow, slowmoving streams with oxygenated water with muddy or sandy bottoms (e.g., A. leorae, VegaLópez and Alvarez-S. 1992, Sunny et al. 2014a,
Monroy-Vilchis et al. 2015; A. rivulare, Brandon and Altig 1973, Bille 2009, Lemos-Espinal et al. 2015; A. rosaceum, Anderson 1961, Anderson and Webb 1978). In order to better understand the specific needs of stream-dwelling Mexican Ambystoma, we need more detailed examinations of their distributions along streams to have a better idea of what specific attributes of streams need to be retained to ensure the persistence of these salamanders.

We found no evidence of sexual dimorphism in the body size (SVL, body mass) of A. leorae. This is consistent with the findings for several other Mexican Ambystoma: A. andersoni Krebs and Brandon, 1984 (Krebs and Brandon 1984); A. granulosum Taylor, 1944 (Aguilar-Miguel et al. 2009); A. lermaense (Taylor, 1940) (AguilarMiguel et al. 2009). However, other species of Mexican Ambystoma are sexually dimorphic with females larger than males (A. rosaceum; Anderson 1961) or males larger than females (A. altimirani; Lemos-Espinal et al. 2016). It is not clear why there are differences among species of Mexican Ambystoma in the extent and direction of sexual dimorphism. One possible explanation that has been tentatively put forth is that sexual dimorphism may be related to the use of ponds and streams (Lemos-Espinal et al. 2016). However, the lack of sexual dimorphism in $A$. leorae and male-biased sexual dimorphism in $A$. altimirani (Lemos-Espinal et al. 2016) argues against such an explanation since both of these 
species are found in streams. Further study is needed to generate possible explanations for such variation.

\section{Conclusions}

Our observations indicate that A. leorae use a variety of sites along the Río Tonatzin, with vegetation type and substrate type being of greater importance, along with dissolved oxygen and substrate color. Larvae were only found in sections with muddy bottoms and aquatic vegetation. Therefore, in order to maintain this population of A. leorae, the current general conditions of the Río Tonatzin need to be maintained. Of particular importance appears to be the maintenance of fish-free streams as LemosEspinal et al. (1999) reported that no A. leorae were found after the introduction of fish into a stream that previously contained A. leorae. Populations of A. leorae may also be endangered by channelization of streams and the use of water by local residents (Vega-López and Alvarez-S. 1992).

\section{Acknowledgments}

Support for this study was provided by Dirección General de Asuntos del Personal Académico - Programa de Apoyo a Proyectos de Investigación e Innovación Tecnológica (DGAPA-PAPIIT), through the Project IN200114, and by Programa de Apoyo a los Profesores de Carrera (PAPCA) of FES-Iztacala UNAM through the Project assigned to RMA: "Historia Natural y Demografia del Ajolote de Arroyo de Montaña (Ambystoma altamirani) en Sierra de las Cruces, México".

\section{References}

Aguilar-Miguel, X., G. Legorreta, and G. Casas-Andreu. 2009. Reproducción ex situ en Ambystoma granulosum y Ambystoma lermaense (Amphibia: Ambystomatidae). Acta Zoológica Mexicana 25: 443-454.

Anderson, J. D. 1961. The life history and systematics of Ambystoma rosaceum. Copeia 1961: 371-377.
Anderson, J. D. and R. G. Webb. 1978. Life history aspects of the Mexican salamadner Ambystoma rosaceum (Amphibia, Urodela, Ambystomatidae). Journal of Herpetology 12: 89-93.

Anderson, J. D. and R. D. Worthington. 1971. The life history of the Mexican salamander Ambystoma ordinarium Taylor. Herpetologica 27: 165-176.

Bille, T. 2009. Field observations on the salamanders (Caudata: Ambystomatidae, Plethodontidae) of Nevado de Toluca, Mexico. Salamandra 45: 155-164.

Brandon, R. A. and R. G. Altig. 1973. Eggs and small larvae of two species of Rhyacosiredon. Herpetologica 29: $349-351$.

Contreras, V., E. Martínez-Meyer, E. Valiente, and L. Zambrano. 2009. Recent decline and potential distribution in the last remnant area of the microendemic Mexican axolotl (Ambystoma mexicanum). Biological Conservation 142: 2881-2885.

Corn, P. S., B. R. Hossack, E. Muths, D. A. Patla, C. R. Peterson, and A. L. Gallant. 2005. Status of amphibians on the Continental Divide: surveys on a transect from Montana to Colorado, USA. Alytes 22: 85-94.

Dyer, W. G. and R. A. Brandon. 1973. New host records of Hedruris siredonis, Falcaustra elongata, and F. mascula from Mexican salamanders. Proceedings of the Helminthological Society of Washington 40: 27-30.

Frías-Alvarez, P., V. T. Vredenburg, M. Familiar-López, J. E. Longcore, E. González-Bernal, G. Santos-Barrera, L. Zambrano, and G. Parra-Olea. 2008. Chytridiomycosis survey in wild and captive Mexican amphibians. EcoHealth 5: 18-26.

Frías-Alvarez, P., J. J. Zúñiga-Vega, and O. Flores-Villela. 2010. A general assessment of the conservation status and decline trends of Mexican amphibians. Biodiversity and Conservation 19: 3699-3742.

García-Romero, A. 2002. An evaluation of forest deterioration in the disturbed mountains of western Mexico City. Mountain Research and Development 22: 270-277.

Gorman, T. A., C. A. Haas, and D. C. Bishop. 2009. Factors related to occupancy of breeding wetlands by Flatwoods Salamander larvae. Wetlands 29: 323-329.

Griffiths, R. A., V. Graue, I. G. Bride, and J. E. McKay. 2004. Conservation of the axolotl (Ambystoma mexicanum) at Lake Xochimilco, Mexico. Herpetological Bulletin 89: 4-11.

Hossack, B. R. and P. S. Corn. 2007. Responses of pondbreeding amphibians to wildfire: short-term patterns in occupancy and colonization. Ecological Applications 17: $1403-1410$. 
Jung, R. E., J. A. Royle, J. R. Sauer, C. Addison, R. D. Rau, J. L. Shirk, and J. C. Whissel. 2005. Estimation of stream salamander (Plethodontidae, Desmognathinae and Plethodontinae) populations in Shenandoah National Park, Virginia, USA. Alytes 22: 72-94.

Krebs, S. L. and R.A. Brandon. 1984. A new species of salamander (Family Ambystomatidae) from Michoacan, Mexico. Herpetologica 40: 238-245.

Kroll, A. J., J. G. MacCracken, T. C. McBride, J. Bakke, J. Light, P. Peterson, and J. Bach. 2010. Basin-scale surveys of stream-associated amphibians in intensively managed forests. Journal of Wildlife Management 74: $1580-1587$.

Lemos-Espinal, J. A. and R. E. Ballinger. 1994. Rhyacosiredon leorae. Size. Herpetological Review 25: 22 .

Lemos-Espinal, J. A., G. R. Smith, R. E. Ballinger, and A. Ramírez-Bautista. 1999. Status of protected endemic salamanders (Ambystoma: Ambystomatidae: Caudata) in the Transvolcanic Belt of México. British Herpetological Society Bulletin 68: 1-4.

Lemos-Espinal, J. A., G. R. Smith, A. H. Ruíz, and R. Montoya-Ayala. 2016. Stream use and population characteristics of the endangered salamander, Ambystoma altamirani, from the Arroyo los Axolotes, State of Mexico, Mexico. Southwestern Naturalist 61: 28-32.

Lemos-Espinal, J. A., G. R. Smith, G. A. Woolrich-Piña, and R. Montoya-Ayala. 2015. Diet of larval Ambystoma rivulare (Caudata: Ambystomatidae), a threatened salamander from the Volcán Nevado de Toluca, Mexico. Phyllomedusa 14: 33-41.

Maldonado-Koerdell, M. 1947. Nota anfibiologicas I. Observaciones sobre algunos anfibios de la Cuenca de México. Revista de Sociedad Mexicana de Historia Natural 8: 229-242.

Mazerolle, M. J., L. L. Bailey, W. L. Kendall, J. A. Royle, S. J. Converse, and J. D. Nichols. 2007. Making great leaps forward: accounting for detectability in herpetological field studies. Journal of Herpetology 41: 672-689.

Mendoza-Almeralla, C., P. Burrowes, and G. Parra-Olea. 2015. La quitridiomicosis en los anfibios de México: una revisión. Revista Mexicana de Biodiversidad 86: 238 248.

Merlín-Uribe, Y., A. Contreras-Hernández, M. AstierCalderón, O. P. Jensen, R. Zaragoza, and L. Zambrano. 2013. Urban expansion into a protected natural area in Mexico City: alternative management scenarios. Journal of Environmental Planning and Management 56: $398-411$.
Monroy-Vilchis, O., M. M. Zarco-González, H. DomínguezVega, and A. Sunny. 2015. Ambystoma leorae (Taylor, 1943). New records, natural history notes and threat status. Herpetozoa 27: 166-168.

Parra-Olea, G., K. R. Zamudio, E. Recuero, X. AguilarMiguel, D. Huacuz, and L. Zambrano. 2012. Conservation genetics of threatened Mexican axolotls (Ambystoma). Animal Conservation 15: 61-72.

Peterman, W. E., J. A. Crawford, and A. R. Kuhns. 2013. Using species distribution and occupancy modeling to guide survey efforts and assess species status. Journal for Nature Conservation 21: 114-121.

SEMARNAT (Secretara de Medio Ambiente y Recursos Naturales). 2010. Norma Oficial Mexicana NOM-059Ecol-2010. Protección ambiental-Especies nativas de México de flora y fauna silvestres-Categorías de riesgo y especifaciones para su inclusion, exclusion o cambioLista de especies en riesgo. Diario official (Segunda Seccion, 30-dic).

Sunny, A., O. Monroy-Vilchis, C. Reyna-Valencia, and M. M. Zarco-González. 2014a. Microhabitat types promote the genetic structure of a micro-endemic and critically endangered mole salamander (Ambystoma leorae) of central Mexico. PLoS ONE 9: e103595.

Sunny, A., O. Monroy-Vilchis, V. Fajardo, and U. AguileraReyes. 2014b. Genetic diversity and structure of an endemic and critically endangered stream river salamander (Caudata; Ambystoma leorae) in Mexico. Conservation Genetics 15: 49-59.

Tanner, W. W. 1989. Amphibians of western Chihuahua. Great Basin Naturalist 49: 38-70.

Taylor, E. H. 1943. Herpetological novelties for Mexico. University of Kansas Science Bulletin 29: 343-361.

Taylor, E. H. and H. M. Smith. 1945. Summary of the collections of amphibians made in México under the Walter Rathbone Bacon traveling scholarship. Proceedings of the United States National Museum 95: 521-613.

Vega-López, A. A. and T. Alvarez-S. 1992. La herpetofauna de los Volcanes Popocatepetl e Iztaccihuatl. Acta Zoologica Mexicana 51: 1-131.

Wilson, L. D., J. D. Johnson, and V. Mata-Silva. 2013. A conservation reassessment of the amphibians of Mexico based on the EVS measure. Amphibian and Reptile Conservation 7: 97-127. 